\title{
Viability of Staphylococcus aureus and expression of its toxins (SEC and TSST-1) in cheeses using Lactobacillus rhamnosus D1 or Weissella paramesenteroides GIR16L4 or both as starter cultures
}

\author{
G. O. Silva, ${ }^{1 *}$ R. D. Castro, ${ }^{1}$ L. G. Oliveira, ${ }^{1}$ F. M. Sant'Anna, ${ }^{1}$ C. D. Barbosa, ${ }^{1}$ S. H. C. Sandes, ${ }^{2}$ R. S. Silva, ${ }^{2}$ \\ M. F. S. Resende, ${ }^{1}$ A. M. Q. Lana, ${ }^{1}$ A. C. Nunes, ${ }^{2}$ M. M. O. P. Cerqueira, ${ }^{1}$ and M. R. Souza ${ }^{1}$ \\ ${ }^{1}$ Departamento de Tecnologia e Inspeção de Produtos de Origem Animal, campus Pampulha da Universidade Federal de Minas Gerais, \\ Belo Horizonte 31270-901, Brazil \\ ${ }^{2}$ Departamento de Genética, Ecologia e Evolução, Universidade Federal de Minas Gerais, Belo Horizonte 31270-901, Brazil
}

\begin{abstract}
Staphylococcus aureus is one of the main causative agents of food poisoning. This bacterium is an important component of cheese microbiota and plays an important role in foodborne diseases. Another important component of the microbiota is the lactic acid bacterium, which actively participates in processes that define the physicochemical, sensorial, and microbiological features of cheese. Of the various microbiological interactions in cheese, the interaction between lactic acid bacteria and Staph. aureus is most relevant. To this end, we evaluated the viability of Staph. aureus strains and the expression of their enterotoxins in cheeses produced experimentally, using Weissella paramesenteroides GIR16L4 or Lactobacillus rhamnosus D1 or both as starter cultures. Over $7 \mathrm{~d}$, we observed that the presence of lactic acid bacteria did not impair Staph. aureus growth. However, via qPCR we observed a change in the gene expression of staphylococcal enterotoxins, suggesting that molecular communication exists between Staph. aureus strains and lactic acid bacteria in cheese. Key words: cheese, staphylococcal enterotoxin, gene expression, lactic acid bacterium
\end{abstract}

\section{INTRODUCTION}

The global food market is constantly challenged to improve technology, production rate, and safety from microbiological contamination. Foods are susceptible to contamination by diverse microorganisms, leading to the development of foodborne diseases in both animals and humans. These diseases could be caused by

Received November 22, 2018.

Accepted January 29, 2020.

*Corresponding author: silvago84@gmail.com the microorganisms themselves or by their metabolites (Stamford et al., 2006). From 1998 to 2015, 19,119 foodborne outbreaks were recorded in the United States (an average of approximately 1,000 cases per year), with 14,681 hospitalizations and 337 deaths (CDC, 2017). In Brazil, from 2007 to 2016, 6,848 foodborne outbreaks were recorded, with 17,517 hospitalizations and 111 deaths. In 2017, 133 outbreaks and 2,014 affected people were recorded in Brazil (Brazil, Ministério da Saúde, Secretaria de Vigilância em Saúde, 2017). The main microbiological agents involved in those outbreaks were Escherichia coli (7.3\%), Salmonella spp. (7.3\%), and Staphylococcus aureus (5.7\%; Brazil, Ministério da Saúde, Secretaria de Vigilância em Saúde, 2016).

Among all etiological agents associated with foodborne outbreaks, Staph. aureus has been reported to be one of the most common pathogenic microorganisms (Le Loir et al., 2003; Stamford et al., 2006). These gram-positive bacteria are the causative agents for bovine mastitis and are responsible for contaminating milk and cheese. Staphylococcus aureus can produce toxic shock proteins, such as toxic shock syndrome toxin 1 (TSST-1), and thermostable enterotoxins, such as staphylococcal enterotoxins, which cause food poisoning commonly characterized by nausea, vomiting, abdominal cramps, and, in some cases, diarrhea (Benkerroum, 2017). To date, 24 staphylococcal enterotoxins have been described, of which SEA, SEB, SEC (1, 2, and 3), SED, and SEE are the most well studied (Benkerroum, 2017).

Cheese contains diverse microorganisms; their interactions determine whether the cheese is safe for consumption as well as the physicochemical and sensorial characteristics of the cheese. These microorganisms include lactic acid bacteria (LAB), which synthesize metabolites that can inhibit the growth of pathogens such as Staph. aureus, Salmonella spp., E. coli, and Listeria monocytogenes (Penido et al., 2018; Sant'Anna et al., 2019). The metabolites include organic acids 
(lactic, propionic, and acetic acids); bacteriocins such as nisin, lacticinin, pediocin, and plantaricin; and hydrogen peroxide (Ross et al., 2000; Dabiza and El-Deib, 2007; Le Marc et al., 2009; Al-Delaimy and Hamamdeh, 2013; Hor and Liong, 2014).

Although several studies have reported the antagonistic activity of LAB strains on pathogenic strains of Staph. aureus, these studies have been limited to in vitro approaches. To date, the inhibitory effect of LAB strains on Staph. aureus growth and enterotoxin gene expression has not been evaluated in cheese. This study evaluated Staph. aureus colonization and sec and tsst 1 gene expression in experimentally produced cheese, using different LAB strains as starter cultures.

\section{MATERIALS AND METHODS}

\section{Bacterial Samples}

In this study, we used 2 Staph. aureus strains: FRI361 (from the Food Research Institute, University of Wisconsin Madison; Otero et al., 1990), a staphylococcal enterotoxin C (SEC) producer $\left(\mathrm{sec}^{+}\right)$; and N315, a methicillin-resistant strain (Kuroda et al., 2001) and an SEC and toxic shock syndrome toxin 1 producer $\left(\sec ^{+}\right.$, tsst $\left.^{+}\right)$. Two LAB strains, Lactobacillus rhamnosus D1 (isolated from Brazilian Minas artisanal cheese) and Weissella paramesenteroides GIR16L4 (isolated from raw milk) were used. The LAB strains have been identified to species level by Sandes et al. (2014) and were used in this study due to their inhibitory effect on other Staph. aureus strains (Costa et al., 2013; Silva, 2016; Acurcio et al., 2017). The Staph. aureus and LAB strains were cultured aerobically in brain heart infusion broth (BHI; Difco, Detroit, MI) and in de Man, Rogosa, and Sharpe broth (MRS; Merck, Darmstadt, Germany), respectively.

\section{In Vitro Approaches}

Susceptibility of Staph. aureus Strains to Lactic Acid. To assess the acid susceptibility of Staph. aureus strains, $1 \mathrm{~mL}$ of stationary-phase cultures of Staph. aureus FRI361 and N315 were inoculated in 100 $\mathrm{mL}$ of BHI, supplemented with $0.1,0.2$, or $0.3 \%$ (vol/ vol) lactic acid. The cultures were incubated at $37^{\circ} \mathrm{C}$ for $18 \mathrm{~h}$. At $0,4,8$, and $18 \mathrm{~h}, 100-\mu \mathrm{L}$ aliquots were collected, diluted in peptone saline, and plated on Baird Parker agar (Difco). Plates were incubated at $37^{\circ} \mathrm{C}$ for $48 \mathrm{~h}$, and viable colonies were counted.

Susceptibility of Staph. aureus to LAB Strains. This assay was performed as previously described (Sandes et al., 2017). Briefly, $5 \mu \mathrm{L}$ of stationary-phase cultures of L. rhamnosus D1 and W. paramesenteroides GIR16L4 were spotted onto MRS agar and incubated under aerobic conditions for $48 \mathrm{~h}$ at $37^{\circ} \mathrm{C}$. Thereafter, the cells were killed by exposing them to chloroform vapor and UV light for $30 \mathrm{~min}$. The Staph. aureus FRI361 and N315 strains were cultured in BHI medium until they reached stationary phase, inoculated into BHI soft agar $(0.75 \% \mathrm{wt} / \mathrm{vol}$ agar $)$, and then overlaid on the surface of MRS plates containing spots of dead LAB strains. After incubating at $37^{\circ} \mathrm{C}$ for $24 \mathrm{~h}$, the inhibitory activity of $\mathrm{LAB}$ was determined by measuring the growth inhibition zone, using a digital pachymeter (Mitutoyo Sul Americana Ltd., São Paulo, Brazil).

\section{In-Cheese Approaches}

Cheesemaking Process. Before cheese production, skim milk powder (Itambé, Belo Horizonte, Brazil) was evaluated for presence of inhibitory substances (Neal and Calbert, 1955), colony-forming units of Staph. aureus (Lancette and Tatini, 2001) and LAB (MacFaddin, 1980), presence of Salmonella spp. (Andrews et al., 2001), and most probable number of coliforms (Kornacki and Johnson, 2001). The presence of staphylococcal enterotoxin genes in skim milk was evaluated via PCR, using 10 pmol each of sec and tsst-1 primer (Table 1), 25 ng of DNA, and master mix from Phoneutria (Belo Horizonte, Brazil) containing $5 \mathrm{U} / \mu \mathrm{L}$ of $\mathrm{Taq}$ polymerase, under the following conditions: $95^{\circ} \mathrm{C}$ for 2 min, 35 cycles of $95^{\circ} \mathrm{C}$ for $30 \mathrm{~s}, 55^{\circ} \mathrm{C}$ for $1 \mathrm{~min}, 72^{\circ} \mathrm{C}$ for $1 \mathrm{~min}$, and final extension at $72^{\circ} \mathrm{C}$ for $5 \mathrm{~min}$.

To produce cheese, a solution of $15 \mathrm{~g}$ of skim milk powder was diluted in $100 \mathrm{~mL}$ of sterile distilled water, heated to $40^{\circ} \mathrm{C}$, and incubated at $37^{\circ} \mathrm{C}$ for $20 \mathrm{~min}$. The last step was performed to completely dissolve solid particles in water. This concentration of milk (15\% wt/vol) was chosen because it produced clots with the highest stability during cheese production. Thereafter, milk was supplemented with rennet and $50 \%$ (wt/vol) $\mathrm{CaCl}_{2}$ solution, and the starter cultures were inoculated as shown in Table 2. After $40 \mathrm{~min}$ of coagulation, the solid phase (curd) was placed in a sterile cheesecloth, and the curd was mixed uniformly with $1 \mathrm{~g}$ of $\mathrm{NaCl}$. The cheese was stored at $7^{\circ} \mathrm{C}$ for $7 \mathrm{~d}$ in a biochemical oxygen demand refrigerator, and small samples were collected on the first and seventh day after production.

Due to loss of bacteria during cheese processing, we plated the cheese samples. For this, $1 \mathrm{~g}$ cheese sample was homogenized, serially diluted, and plated in MRS or Baird-Parker medium. Sample collection for physicochemical, microbiological, and molecular assays was performed only when bacterial populations reached $10^{8}$ $\mathrm{cfu} / \mathrm{g}$, this point being considered $\mathrm{d} 0$. 


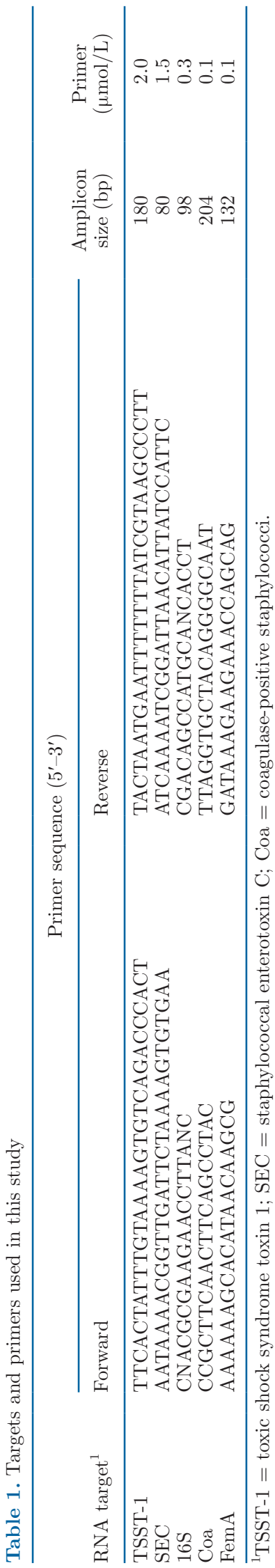

Physicochemical and Microbiological Analyses. The different cheeses produced were physicochemically analyzed for (1) moisture content, by the gravimetric method (IDF, 2004a); (2) nitrogenous compounds, by the Kjeldahl method (IDF, 2004b); (3) titratable acidity (Merck, 1993); and (4) pH, using an indicator strip. For microbiological analyses, $10 \mathrm{~g}$ of cheese was weighed and homogenized using a stomacher (MK1204, Boitton, Porto Alegre, Brazil) in $90 \mathrm{~mL}$ of $0.1 \% \mathrm{NaCl}$ (wt/vol) solution, corresponding to $10^{-1}$ dilution. Thereafter, samples were serially diluted to $10^{-6}$ and plated by the spread-plate method on Baird-Parker (Lancette and Tatini, 2001) or MRS agar (MacFaddin, 1980) to perform counts for Staph. aureus and LAB strains, respectively. For these assays, samples were collected on the first and seventh days of storage. The physicochemical and microbiological analyses were performed in triplicate.

$\boldsymbol{R} \boldsymbol{N A}$ Isolation. The RNA assay was performed as previously described (Ulve et al., 2008; Sandes et al., 2017). Briefly, total RNA was isolated from $3 \mathrm{~g}$ of cheese stored for 1 and $7 \mathrm{~d}$. The quality and quantity of RNA were evaluated using agarose gel electrophoresis and a NanoDrop 2000 spectrophotometer (Thermo Fisher Scientific, Waltham, MA), measuring absorbance ratios at $280 / 260$ and $260 / 230 \mathrm{~nm}$. Samples were treated with turbo DNase (Ambion, Austin, TX) for cDNA synthesis, which was performed using $1 \mu \mathrm{g}$ of RNA and a High-Capacity cDNA Reverse Transcription Kit (Applied Biosystems, Foster City, CA), according to the manufacturer's instructions.

Expression Analysis of sec and tsst1. Quantitative reverse transcription (qRT)-PCR was performed using iTaq Universal SYBR Green Supermix (Bio-Rad, Hercules, CA) and gene-specific primers for sec and tsst1, as described by Klotz et al. (2003) and Jarraud et al. (2002). The housekeeping gene 16S was used for normalization (Huse et al., 2008). Experimental approach was optimized by adjusting primer concentration for optimal specificity and efficiency (Table 1). Amplification was performed using the following protocol: initial step, $95^{\circ} \mathrm{C}$ for $30 \mathrm{~s}$, followed by 40 cycles of $95^{\circ} \mathrm{C}$ for 15 $\mathrm{s}$, and $60^{\circ} \mathrm{C}$ for $1 \mathrm{~min}$. The dissociation curve was obtained as follows: $95^{\circ} \mathrm{C}$ for $15 \mathrm{~s}, 60^{\circ} \mathrm{C}$ for $15 \mathrm{~s}$, and $95^{\circ} \mathrm{C}$ for $15 \mathrm{~s}$. Expression levels in cheese inoculated only with FRI361 $\left(\mathrm{sec}^{+}\right)$or with N315 $\left(\right.$tsst $\left.^{+}\right)$strains were used for calibration. Results have been shown graphically as fold-change in gene expression, using mean and standard deviation of the amount of gene expression, according to Hellemans et al. (2007).

Contaminant Analysis. Molecular analyses were performed in the control cheese (without inoculum) to verify eventual cross-contamination between cheeses, by using specific primers for coagulase-positive staphy- 
Table 2. Combinations of Staphylococcus aureus and lactic acid bacteria strains used for cheesemaking

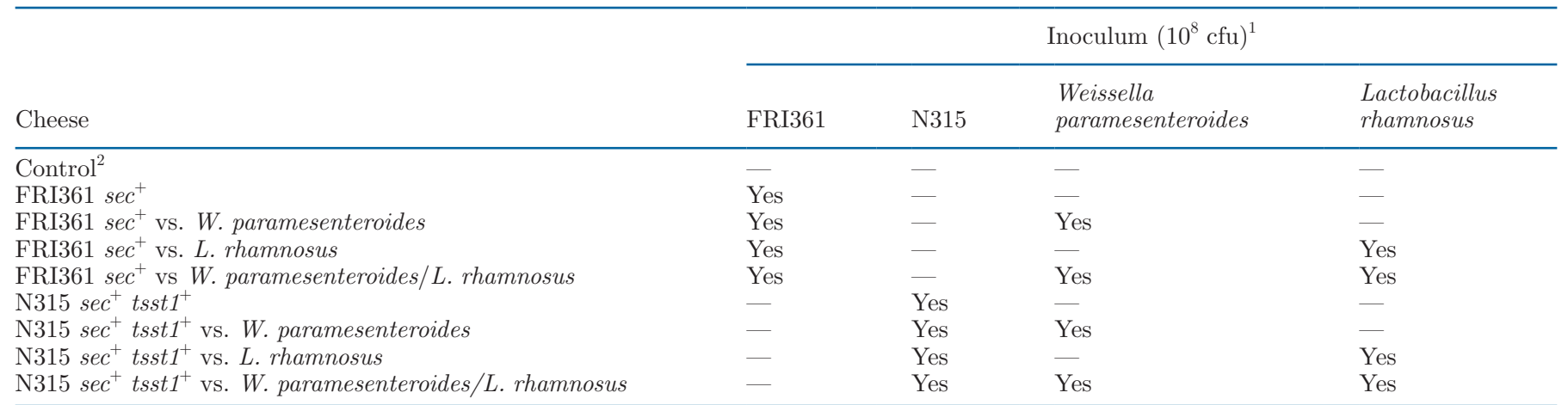

${ }^{1}$ Staphylococcus aureus and lactic acid bacteria were cultured in brain heart infusion broth and de Man, Rogosa, and Sharpe broth, respectively, until stationary phase was reached. Thereafter, bacterial samples were serially diluted, and the inoculum concentration was adjusted to $10^{8}$ cfu. Experimental cheeses were inoculated with Staphylococcus aureus strains FRI361, a staphylococcal enterotoxin C producer (SEC; sec ${ }^{+}$), and N315, a methicillin-resistant strain and an SEC and toxic shock syndrome toxin 1 producer $\left(\sec ^{+}\right.$tsst $\left.^{+}\right)$.

${ }^{2}$ No inoculum was used.

lococci (Coa) and Staph. aureus (FemA; Table 1). Cheese samples inoculated with FRI361 or with N315 were used as positive controls, as these were treated only with Staph. aureus during production. The cDNAs were amplified by PCR using $0.2 \mu \mathrm{L}$ of each primer and $2.5 \mathrm{ng}$ of cDNA, under the following conditions: $94^{\circ} \mathrm{C}$ for 5 min, 35 cycles of $94^{\circ} \mathrm{C}$ for $2 \mathrm{~min}, 56^{\circ} \mathrm{C}$ for 2 min (Coa) or $57^{\circ} \mathrm{C}$ for $2 \mathrm{~min}(\mathrm{FemA}), 68^{\circ} \mathrm{C}$ for $1 \mathrm{~min}$, and final extension $72^{\circ} \mathrm{C}$ for $7 \mathrm{~min}$. Furthermore, contamination was analyzed via $\mathrm{qPCR}$ for sec and tsst-1, to ascertain whether the toxins studied were present, as they could be expressed only by coagulase-negative staphylococci. The conditions used in the reaction have been described previously.

\section{Statistical Analysis}

All assays were performed in triplicate with 3 independent repetitions. A total of 9 different cheeses were produced in triplicate (Table 1) and stored for $1 \mathrm{~d}$. Another batch of 9 different cheeses was produced under the same conditions and stored for $7 \mathrm{~d}$. Data were analyzed in GraphPad Prism 6 (GraphPad Software Inc., La Jolla, CA). The Shapiro-Wilk test was used to determine data distribution. Parameterized samples were analyzed through one-way ANOVA to evaluate differences between groups inside a period, or through 2-way ANOVA to evaluate differences between groups in different periods. Dunnett's correction was employed as post hoc multiple comparison test, considering a level of significance higher than 95\% $(P<0.05)$. Non-parameterized samples were also submitted to ANOVA and Duncan's tests. Student-Newman-Keuls and Friedman tests were used for microbiological and physicochemical assays, respectively.

\section{RESULTS AND DISCUSSION}

\section{Skim Milk Powder Standard}

Staphylococcus aureus, thermotolerant coliforms, Salmonella spp., and LAB strains were not detected in the skim milk powder.

\section{Staph. aureus FRI361 and N315 are Resistant to Lactic Acid}

Staphylococcus aureus strains FRI361 and N315 were able to multiply in the presence of $0.1,0.2$, and $0.3 \%$ lactic acid (Figure 1), suggesting that these strains were acid tolerant. These results contradict other studies, which showed an inhibitory effect of lactic acid produced by LAB strains on Staph. aureus growth (Alomar et al., 2008; Charlier et al., 2008; Al-Delaimy and Hamamdeh, 2013; Hor and Liong, 2014; Nouaille et al., 2014). Therefore, we speculated that the inhibition of Staph. aureus strains by LAB may be due to the action of other inhibitory substances, such as bacteriocins or hydrogen peroxide (Sandes et al., 2017).

\section{Physicochemical Analyses}

Control cheeses showed 72.47 and $71.16 \%$ moisture and 16.29 and $15.12 \%$ total protein at d 1 and 7 after processing, respectively. These values are within the standards established by Brazilian legislation for cheeses with very high moisture content (Brazil, Ministério da Agricultura, Pecuária e Abastecimento, Secretaria de Defesa Agropecuária, 1996). Mean results for titratable acidity and $\mathrm{pH}$ of cheeses treated with different conditions are shown in Tables 3 and 4. 
Table 3. Means of titratable acidity and $\mathrm{pH}$ in cheese prepared using different lactic acid bacteria strains and Staphylococcus aureus FRI361, a staphylococcal enterotoxin $\mathrm{C}$ producer $\left(\sec ^{+}\right)$, stored at $7^{\circ} \mathrm{C}$ for 1 and $7 \mathrm{~d}$

\begin{tabular}{|c|c|c|c|c|}
\hline \multirow[b]{2}{*}{ Cheese } & \multicolumn{2}{|c|}{ Titratable acidity (\%) } & \multicolumn{2}{|c|}{$\mathrm{pH}$} \\
\hline & Day 1 & Day 7 & Day 1 & Day 7 \\
\hline FRI361 $\sec ^{+}$ & $0.021^{\mathrm{BC}, \mathrm{a}}$ & $0.035^{\mathrm{B}, \mathrm{b}}$ & $7.0^{\mathrm{A}, \mathrm{a}}$ & $7.0^{\mathrm{A}, \mathrm{a}}$ \\
\hline FRI361 $\mathrm{sec}^{+}$vs. Weissella paramesenteroides & $0.021^{\mathrm{C}, \mathrm{a}}$ & $0.052^{\mathrm{AB}, \mathrm{b}}$ & $6.5^{\mathrm{B}, \mathrm{a}}$ & $6.0^{\mathrm{B}, \mathrm{a}}$ \\
\hline FRI361 $\mathrm{sec}^{+}$vs. Lactobacillus rhamnosus & $0.022^{\mathrm{B}, \mathrm{ca}}$ & $0.042^{\mathrm{B}, \mathrm{a}}$ & $7.0^{\mathrm{A}, \mathrm{a}}$ & $6.0^{\mathrm{B}, \mathrm{b}}$ \\
\hline FRI361 $\mathrm{sec}^{+}$vs. $W$. paramesenteroides $/$ L. rhamnosus & $0.028^{\mathrm{B}, \mathrm{a}}$ & $0.095^{\mathrm{A}, \mathrm{b}}$ & $5.7^{\mathrm{C}, \mathrm{a}}$ & $5.5^{\mathrm{C}, \mathrm{a}}$ \\
\hline
\end{tabular}

$\overline{{ }^{\mathrm{A}} \mathrm{C}}$ Different uppercase superscripts in columns indicate that comparison between groups was statistically different $(P<0.05)$.

${ }^{\mathrm{a}, \mathrm{b}}$ Different lowercase superscripts in rows indicate that comparison between groups was statistically different $(P<0.05)$.

Over $7 \mathrm{~d}$ of storage we observed an increase in titratable acidity in all inoculated cheeses (Tables 3 and 4), probably due to acid produced during microbial metabolism. No statistical differences were observed in the $\mathrm{pH}$ of the cheeses inoculated with Staph. aureus alone (Tables 3 and 4 ). In contrast, the use of LAB as starter culture reduced the $\mathrm{pH}$ over the time of storage, especially for cheeses made with Staph. aureus FRI361 and L. rhamnosus D1; Staph. aureus N315, W. paramesenteroides GIR16L4, or L. rhamnosus D1; and Staph. aureus N315, W. paramesenteroides GIR16L4, and $L$. rhamnosus D1 $(P<0.05)$.

\section{Microbiological Analyses}

As stated earlier, microorganisms were not detected in milk powder, attesting to its quality and safety as a raw material for cheesemaking. Although the cheeses were produced under sterile conditions, we observed growth of LAB and staphylococci in control samples, which were produced without bacterial inoculation (Tables 5 and 6). This can be explained by possible contamination after processing or during storage, or both. However, LAB counts in these cheeses were statistically lower than LAB counts observed in other cheeses $(P<$ 0.05). Regarding staphylococci growth, a similar observation was made: control cheese showed lower counts of
Staph. aureus compared with those subjected to other treatments $(P<0.05$; Tables 5 and 6$)$. This result was expected, as control cheeses were not inoculated with Staph. aureus.

To evaluate whether the contamination could have interfered with subsequent analyses, we performed PCR for coagulase-positive Staph. aureus, using CoA and FemA primers; no amplicon was detected, indicating that the control cheese was not contaminated with coagulase-positive Staph. aureus (data not shown). Moreover, when we performed qPCR for sec and tsst1, no difference in relative gene expression was observed between d 1 (without contamination) and d 7 (with contamination), indicating that contamination of the control cheese did not change the relative gene expression of the toxins (Figure 2).

Regarding storage time, no difference in Staph. aureus count was observed between the different cheeses except in the control cheese and in the cheese inoculated with Staph. aureus N315, W. paramesenteroides, and $L$. rhamnosus (Table 6). Although the $\mathrm{pH}$ of the cheeses decreased with storage time, it was not sufficient to decrease Staph. aureus growth (Tables 3-6). Moreover, in the present study, the growth of Staph. aureus FRI361 and N315 were not affected by LAB, demonstrating that these strains were resistant to environmental and microbiological changes. This result could be a warn-

Table 4. Means of titratable acidity and $\mathrm{pH}$ in cheese prepared using different lactic acid bacteria strains and Staphylococcus aureus N315, a methicillin-resistant strain that is a staphylococcal enterotoxin $\mathrm{C}$ producer $\left(\sec ^{+}\right)$and a toxic shock syndrome toxin 1 producer $\left(t s s t 1^{+}\right)$, stored at $7^{\circ} \mathrm{C}$ for 1 and $7 \mathrm{~d}$

\begin{tabular}{|c|c|c|c|c|}
\hline Cheese & \multicolumn{2}{|c|}{ Titratable acidity (\%) } & \multicolumn{2}{|c|}{$\mathrm{pH}$} \\
\hline $\begin{array}{l}\text { Control } \\
\text { N315 sec } \text { tsst }^{+} \\
\text {N315 } \text { sec }^{+} \text {tsst } 1^{+} \text {vs. Weissella paramesenteroides } \\
\text { N315 sec }{ }^{+} \text {tsst } 1^{+} \text {vs. Lactobacillus rhamnosus } \\
\text { N315 } \text { sec }^{+} \text {tsst } 1^{+} \text {vs. } W \text {. paramesenteroides } / \text { L. rhamnosus }\end{array}$ & $\begin{array}{l}0.034^{\mathrm{A}, \mathrm{a}} \\
0.017^{\mathrm{CD}, \mathrm{a}} \\
0.020^{\mathrm{C}, \mathrm{a}} \\
0.014^{\mathrm{D}, \mathrm{a}} \\
0.027^{\mathrm{B}, \mathrm{a}}\end{array}$ & $\begin{array}{l}0.029^{\mathrm{B}, \mathrm{a}} \\
0.030^{\mathrm{B}, \mathrm{b}} \\
0.049^{\mathrm{A}, \mathrm{b}} \\
0.038^{\mathrm{B}, \mathrm{b}} \\
0.057^{\mathrm{AB}, \mathrm{b}}\end{array}$ & $\begin{array}{l}7.0^{\mathrm{A}, \mathrm{a}} \\
7.0^{\mathrm{A}, \mathrm{a}} \\
6.6^{\mathrm{A}, \mathrm{a}} \\
7.0^{\mathrm{A}, \mathrm{a}} \\
6.0^{\mathrm{B}, \mathrm{a}}\end{array}$ & $\begin{array}{l}7.0^{\mathrm{A}, \mathrm{a}} \\
7.0^{\mathrm{A}, \mathrm{a}} \\
5.8^{\mathrm{C}, \mathrm{b}} \\
6.5^{\mathrm{B}, \mathrm{b}} \\
5.5^{\mathrm{C}, \mathrm{b}}\end{array}$ \\
\hline
\end{tabular}

$\overline{\mathrm{A}-\mathrm{D}}$ Different uppercase superscripts in columns indicate that comparison between groups was statistically different $(P<0.05)$.

${ }^{\mathrm{a}, \mathrm{b}}$ Different lowercase superscripts in rows indicate that comparison between groups was statistically different $(P<0.05)$. 
361

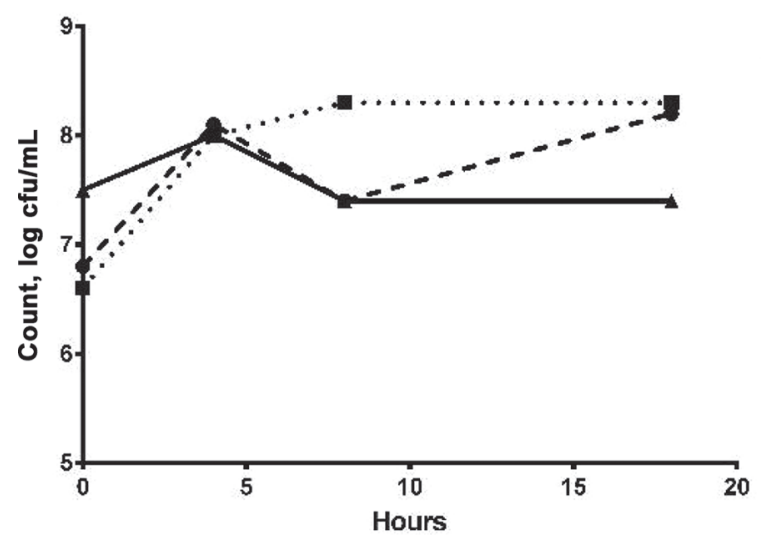

315

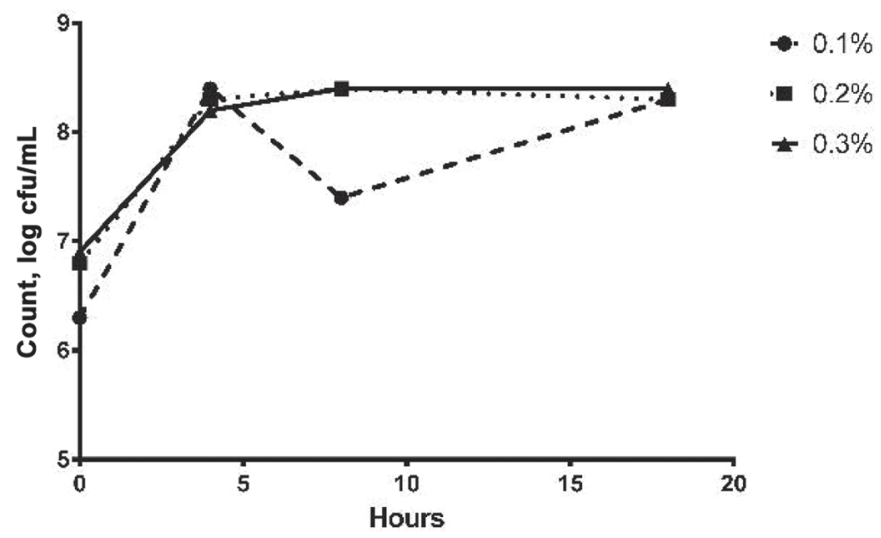

Figure 1. Staphylococcus aureus growth (strains FRI361 and N315) in 0.1, 0.2, and 0.3\% lactic acid.

ing, as Staph. aureus counts found in this study can be considered high enough to trigger toxin production that could result in staphylococcal poisoning (Jay et al., 2005).

\section{Toxin Expression}

When we compared the relative expression of toxins in cheese inoculated with Staph. aureus N315 (Figure $3 \mathrm{a}$ and $\mathrm{b}$ ), we observed reduced tsst 1 and sec expression from $\mathrm{d} 1$ to the $\mathrm{d} 7(P<0.05)$, suggesting high initial toxin levels followed by a decrease in toxin levels, which may be explained by a physiological adaptation process, wherein the synthesis of virulence factors was reduced. We also observed that when Staph. aureus N315 was co-inoculated with $W$. paramesenteroides or L. rhamnosus or both, initial expression levels of tsst 1 and sec were reduced, compared with cheese inoculated with N315 alone, and remained at low levels during 7 $\mathrm{d}$ of storage. These results lead us to speculate that expression of these genes could be regulated by the same quorum-sensing mechanism; however, this hypothesis needs to be tested further.

When we analyzed sec expression in cheeses inoculated with Staph. aureus FRI361 (Figure 3c), we observed that co-inoculation with $W$. paramesenteroides or L. rhamnosus or both triggered higher expression of toxins, which was reduced through d 7 of incubation. On d 1 of storage, the cheeses inoculated with Staph. aureus FRI361 behaved in an opposite manner to the cheeses inoculated with Staph. aureus N315, where LAB co-inoculation induced sec expression, indicating that FRI361 might be regulated by a different quorumsensing mechanism than N315.

Previously, similar results have been described. Even et al. (2009) evaluated gene expression of virulence factors in Staph. aureus cocultured with Lactococcus lactis and observed that several regulatory virulence factors genes, such as agr and sarA, were underexpressed. Duquenne et al. (2010) co-inoculated Staph. aureus, L. lactis, and Lactococcus cremoris in cheeses and reported decreased expression of sea and sed over

Table 5. Average count of lactic acid bacteria and Staphylococcus aureus FRI361, a staphylococcal enterotoxin C producer (sec ${ }^{+}$; log cfu/g) in cheese stored at $7^{\circ} \mathrm{C}$ for 1 and $7 \mathrm{~d}^{1}$

\begin{tabular}{|c|c|c|c|c|}
\hline \multirow[b]{2}{*}{ Cheese } & \multicolumn{2}{|c|}{ Lactic acid bacteria } & \multicolumn{2}{|c|}{$\begin{array}{c}\text { Staphylococcus aureus } \\
\text { FRI361 sec }\end{array}$} \\
\hline & Day 1 & Day 7 & Day 1 & Day 7 \\
\hline FRI361 $\sec ^{+}$ & $\mathrm{ND}^{\mathrm{A}, \mathrm{a}}$ & $\mathrm{ND}^{\mathrm{C}, \mathrm{a}}$ & $7.08^{\mathrm{B}, \mathrm{a}}$ & $7.61^{\mathrm{B}, \mathrm{a}}$ \\
\hline FRI361 sec $^{+}$vs. Weissella paramesenteroides & $6.87^{\mathrm{B}, \mathrm{a}}$ & $7.85^{\mathrm{B}, \mathrm{b}}$ & $7.32^{\mathrm{B}, \mathrm{a}}$ & $7.87^{\mathrm{B}, \mathrm{a}}$ \\
\hline FRI361 $\mathrm{sec}^{+}$vs. Lactobacillus rhamnosus & $6.84^{\mathrm{B}, \mathrm{a}}$ & $7.71^{\mathrm{B}, \mathrm{b}}$ & $7.22^{\mathrm{B}, \mathrm{a}}$ & $7.82^{\mathrm{B}, \mathrm{a}}$ \\
\hline
\end{tabular}

\footnotetext{
${ }^{\mathrm{A}-\mathrm{C}}$ Different uppercase superscripts in columns indicate that comparison between groups was statistically different $(P<0.05)$.

${ }^{\mathrm{a}, \mathrm{b}}$ Different lowercase superscripts in rows indicate that comparison between groups was statistically different $(P<0.05)$.

${ }^{1} \mathrm{ND}=$ not detected.
} 
Table 6. Average count of lactic acid bacteria and Staphylococcus aureus N315, a methicillin-resistant strain that is a staphylococcal enterotoxin $\mathrm{C}$ producer $\left(\mathrm{sec}^{+}\right)$and a toxic shock syndrome toxin 1 producer $\left(t s s t^{+} ; \log \mathrm{cfu} / \mathrm{g}\right)$ in cheese stored at $7^{\circ} \mathrm{C}$ for 1 and $7 \mathrm{~d}^{1}$

\begin{tabular}{|c|c|c|c|c|}
\hline \multirow[b]{2}{*}{ Cheese } & \multicolumn{2}{|c|}{ Lactic acid bacteria } & \multicolumn{2}{|c|}{$\begin{array}{l}\text { Staphylococcus aureus } \\
\text { N315 } \text { sec }^{+} \text {tsst }^{+}\end{array}$} \\
\hline & Day 1 & Day 7 & Day 1 & Day 7 \\
\hline N315 $\sec ^{+}$tsst $1^{+}$ & $\mathrm{ND}^{\mathrm{A}, \mathrm{a}}$ & $\mathrm{ND}^{\mathrm{C}, \mathrm{a}}$ & $7.07^{\mathrm{B}, \mathrm{a}}$ & $7.58^{\mathrm{B}, \mathrm{a}}$ \\
\hline $\mathrm{N} 315$ sec $^{+}$tsst $^{+}$vs. Weissella paramesenteroides & $7.40^{\mathrm{B}, \mathrm{a}}$ & $7.63^{\mathrm{B}, \mathrm{a}}$ & $7.49^{\mathrm{B}, \mathrm{a}}$ & $7.72^{\mathrm{B}, \mathrm{a}}$ \\
\hline $\mathrm{N} 315$ sec $^{+}$tsst $^{+}$vs. Lactobacillus rhamnosus & $6.99^{\mathrm{B}, \mathrm{a}}$ & $7.71^{\mathrm{B}, \mathrm{b}}$ & $7.53^{\mathrm{B}, \mathrm{a}}$ & $7.46^{\mathrm{B}, \mathrm{a}}$ \\
\hline
\end{tabular}

${ }^{\mathrm{A}-\mathrm{C}}$ Different uppercase superscripts in columns indicate that comparison between groups was statistically different $(P<0.05)$.

${ }^{\mathrm{a}, \mathrm{b}}$ Different lowercase superscripts in rows indicate that comparison between groups was statistically different $(P<0.05)$.

${ }^{1} \mathrm{ND}=$ not detected.

72 h. Nouaille et al. (2014) investigated the interaction between L. lactis ssp. lactis and Staph. aureus, suggesting the capacity of LAB to modulate agr expression in Staph. aureus.

\section{CONCLUSIONS}

The results obtained in the present study show that the $W$. paramesenteroides GIR16L4 and L. rhamnosus D1 strains were not able to impair the growth of Staph. aureus FRI361 and N315 strains in cheeses produced experimentally. However, LAB may be able to change the expression of staphylococcal toxins in a strain-dependent manner. These results must be fur- ther analyzed to determine the mechanisms of quorum sensing through which LAB modulates expression of staphylococcal toxins.

\section{ACKNOWLEDGMENTS}

The authors thank Luiz Simeão do Carmo (FUNED, Belo Horizonte, Brazil) for providing the Staph. aureus FRI361 strain and Marjory Xavier Rodrigues (ESALQ-USP, Piracicaba, Brazil) for providing the Staph. aureus N315 strain. This study was supported with funds from Fundação de Amparo à Pesquisa do Estado de Minas Gerais (FAPEMIG, Belo Horizonte, Brazil), the Brazilian National Council for Scientific
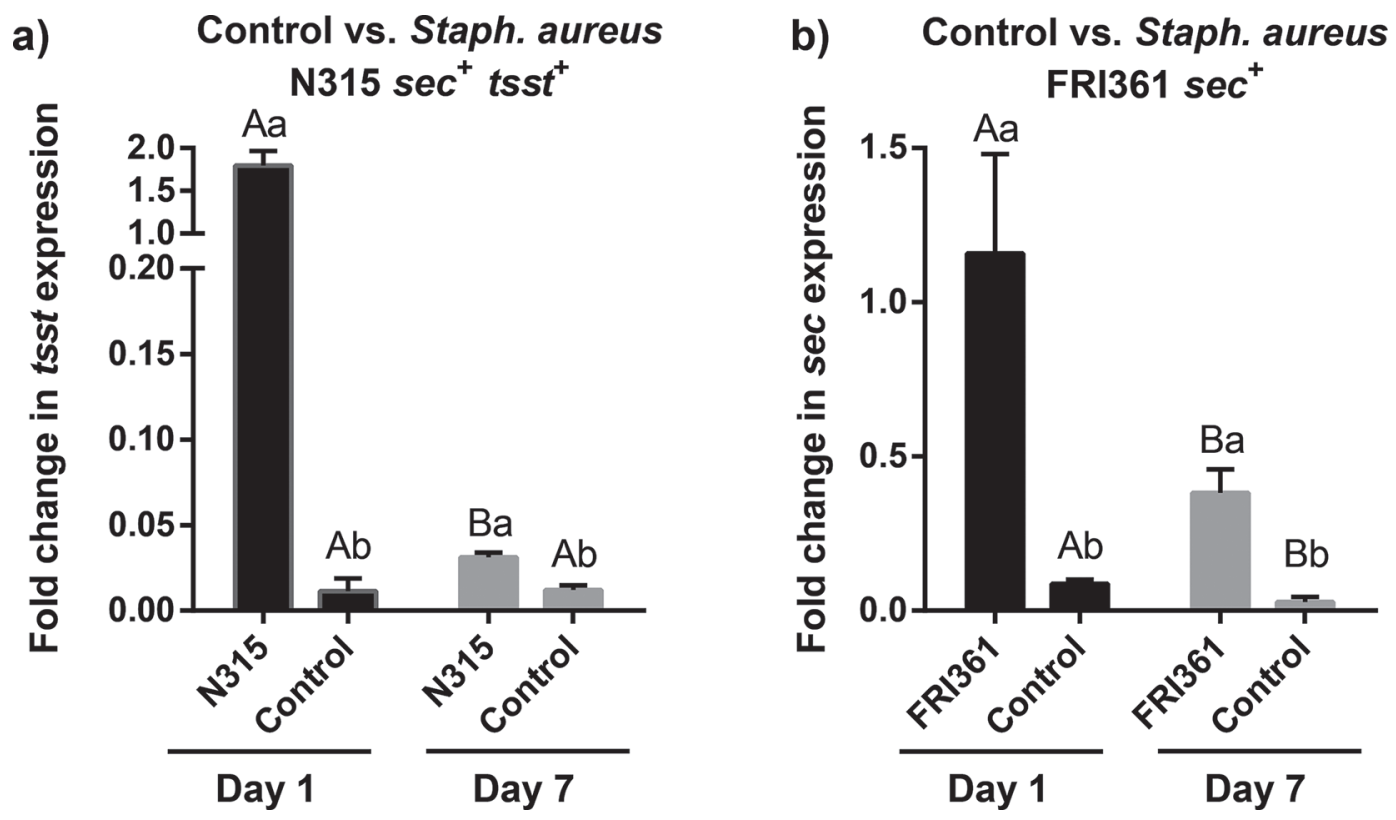

Figure 2. Fold changes in gene expression of (a) toxic shock syndrome toxin 1 (tsst1) and (b) staphylococcal enterotoxin C (sec) in control cheeses (without inoculation) compared with cheeses inoculated with Staphylococcus aureus N315 (sec ${ }^{+}$tsst $^{+}$) or Staph. aureus FRI361 (sec ${ }^{+}$). Different uppercase letters indicate that comparison between the same groups on $\mathrm{d} 1$ and $\mathrm{d} 7$ was statistically different $(P<0.05)$. Different lowercase letters indicate that comparison between groups on the same day was statistically different $(P<0.05)$. 

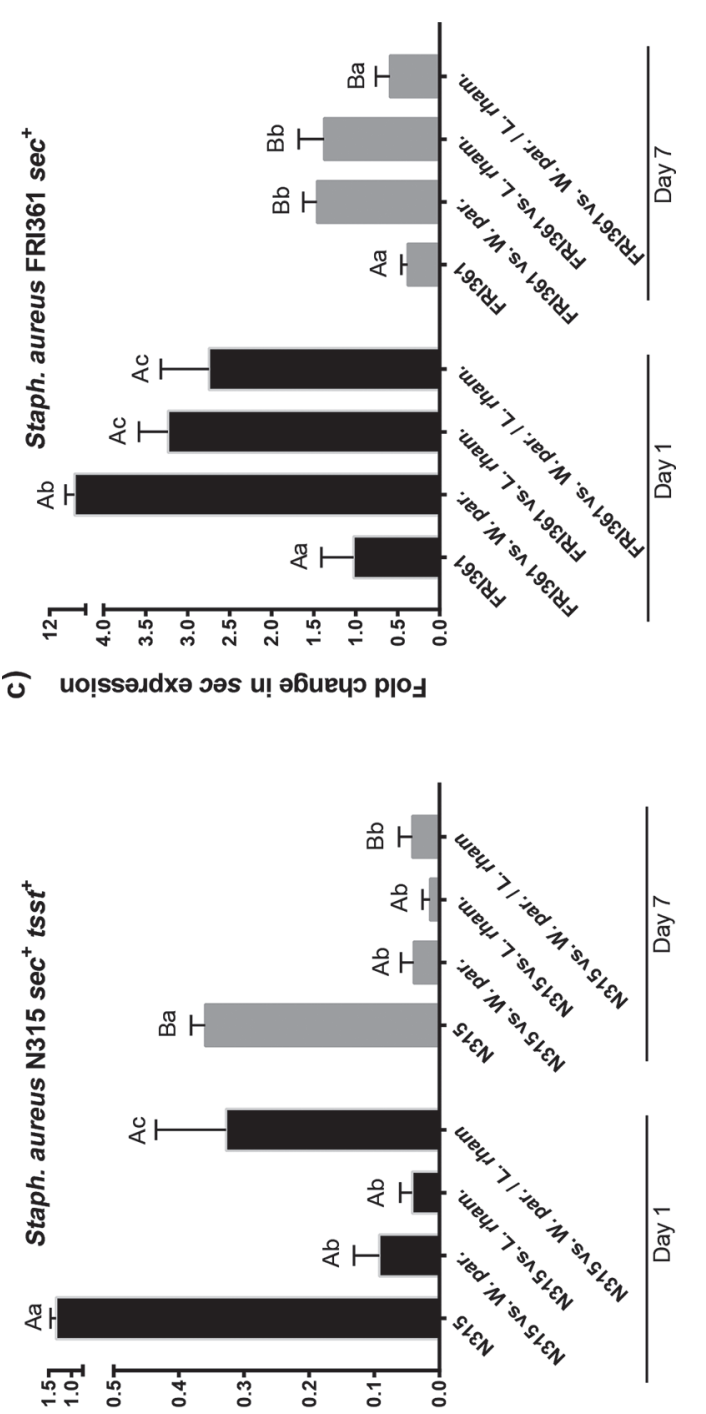

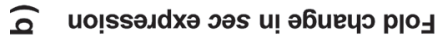

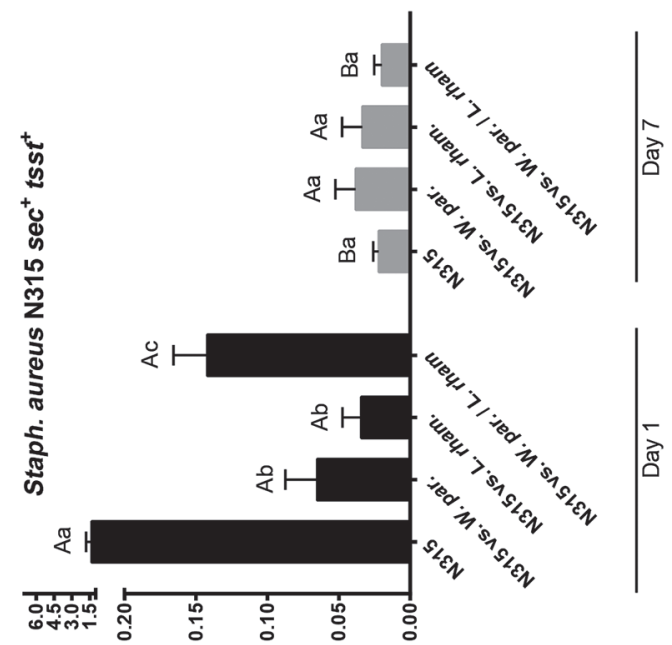

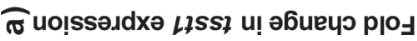

and Technological Development (CNPQ, Brasilia), and Coordenação de Aperfeiçoamento de Pessoal de Nível Superior (CAPES, Brasilia, Brazil). The authors have not stated any conflicts of interest.

\section{REFERENCES}

Acurcio, L. B., S. H. C. Sandes, R. W. Bastos, F. M. Sant'anna, S. H. S. P. Pedroso, D. C. Reis, A. C. Nunes, G. D. Cassali, M. R. Souza, and J. R. Nicoli. 2017. Milk fermented by Lactobacillus species from Brazilian artisanal cheese protect germ-free-mice against Salmonella Typhimurium infection. Benef. Microbes 8:579-588. https: //doi.org/10.3920/BM2016.0163.

Al-Delaimy, K. S., and Y. M. Hamamdeh. 2013. Inhibition of Staphylococcus aureus by lactic acid bacteria and/or Bifidobacterium lactis during milk fermentation and storage. J. Microbiol. Biotechnol. Food Sci. 2:2406.

Alomar, J., P. Loubiere, C. Delbes, S. Nouaille, and M.-C. Montel 2008. Effect of Lactococcus garvieae, Lactococcus lactis and Enterococcus faecalis on the behavior of Staphylococcus aureus in microfiltered milk. Food Microbiol. 25:502-508. https://doi.org/10 $.1016 / j . f m .2008 .01 .005$.

Andrews, W. H., R. S. Flowers, J. Silliker, and J. S. Bailey. 2001. Salmonella. Pages 357-376 in Compendium of Methods for the Microbiological Examination of Foods. 4th ed. F. P. Downes and K. Ito, ed. Am. Public Health Assoc, Washington, DC.

Benkerroum, N. 2017. Staphylococcal enterotoxins and enterotoxinlike toxins with special reference to dairy products: An overview. Crit. Rev. Food Sci. Nutr. 58:1943-1970. https://doi.org/10.1080/ 10408398.2017.1289149.

Brazil, Ministério da Agricultura, Pecuária e Abastecimento, Secretaria de Defesa Agropecuária. 1996. Portaria n. 147, de 07 de março de 1996. Regulamentos Técnicos de Identidade e Qualidade dos Produtos Lácteos. Diário Oficial da União.

Brazil, Ministério da Saúde, Secretaria de Vigilância em Saúde. 2016. Surtos de Doenças Transmitidas por Alimentos no Brasil. Accessed May 13, 2017. http://portalarquivos.saude.gov.br/images/ pdf/2016/dezembro/09/Apresentacao-Surtos-DTA-2016.pdf.

Brazil, Ministério da Saúde, Secretaria de Vigilância em Saúde. 2017. Surtos de Doenças Transmitidas por Alimentos no Brasil. Accessed Jul. 4, 2017. http://portalarquivos.saude.gov.br/images/ pdf/2017/maio/29/Apresentacao-Surtos-DTA-2017.pdf.

CDC (Centers for Disease Control and Prevention). Foodborne Outbreak Online Database. 2017. Accessed Apr. 27, 2017. https:// wwwn.cdc.gov/foodborneoutbreaks/Default.aspx/.

Charlier, C., S. Even, M. Gautier, and Y. Le Loir. 2008. Acidification is not involved in the early inhibition of Staphylococcus aureus growth by Lactococcus lactis in milk. Int. Dairy J. 18:197-203. https://doi.org/10.1016/j.idairyj.2007.03.015.

Costa, H., M. Souza, L. Acúrcio, A. Cunha, M. Resende, and A. Nunes. 2013. Potencial probiótico in vitro de bactérias ácido-láticas isoladas de queijo-de-minas artesanal da Serra da Canastra, MG. Arq. Bras. Med. Vet. Zootec. 65:1858-1866. https://doi.org/10.1590/ S0102-09352013000600038.

Dabiza, N., and K. El-Deib. 2007. Biochemical evaluation and microbial quality of Ras cheese supplemented with probiotic strains. Pol. J. Food Nutr. Sci. 57:295-300.

Duquenne, M., I. Fleurot, M. Aigle, C. Darrigo, E. Borezée-Durant, S. Derzelle, M. Bouix, V. Deperrois-Lafarge, and A. DelacroixBuchet. 2010. Tool for quantification of staphylococcal enterotoxin gene expression in cheese. Appl. Environ. Microbiol. 76:1367-1374. https://doi.org/10.1128/AEM.01736-09.

Even, S., C. Charlier, S. Nouaille, N. L. Ben Zakour, M. Cretenet, F. J. Cousin, M. Gautier, M. Cocaign-Bousquet, P. Loubière, and Y. Le Loir. 2009. Staphylococcus aureus virulence expression is impaired by Lactococcus lactis in mixed cultures. Appl. Environ. Microbiol. 75:4459-4472. https://doi.org/10.1128/AEM.02388-08.

Hellemans, J., G. Mortier, A. De Paepe, F. Speleman, and J. Vandesompele. 2007. qBase relative quantification framework and soft- 
ware for management and automated analysis of real-time quantitative PCR data. Genome Biol. 8:R19. https://doi.org/10.1186/ gb-2007-8-2-r19.

Hor, Y. Y., and M. T. Liong. 2014. Use of extracellular extracts of lactic acid bacteria and bifidobacteria for the inhibition of dermatological pathogen Staphylococcus aureus. Zhonghua Pifuke Yixue Zazhi 32:141-147. https://doi.org/10.1016/j.dsi.2014.03.001.

Huse, S. M., L. Dethlefsen, J. A. Huber, D. M. Welch, D. A. Relman, and M. L. Sogin. 2008. Exploring microbial diversity and taxonomy using SSU rRNA hypervariable tag sequencing. PLoS Genet. 4:e1000255. https://doi.org/10.1371/journal.pgen.1000255.

IDF (International Dairy Federation). 2004a. Cheese and processed cheese: Determination of total solids content. IDF Standard 004. Int. Dairy Fed., Brussels, Belgium.

IDF (International Dairy Federation). 2004b. Milk: Determination of nitrogen content. IDF Standard 020-3. Int. Dairy Fed., Brussels, Belgium.

Jarraud, S., C. Mougel, J. Thioulouse, G. Lina, H. Meugnier, F. Forey, X. Nesme, J. Etienne, and F. Vandenesch. 2002. Relationships between Staphylococcus aureus genetic background, virulence factors, agr groups (alleles), and human disease. Infect. Immun. 70:631-641. https://doi.org/10.1128/IAI.70.2.631-641.2002.

Jay, J. M., M. J. Loessner, and D. A. Golden. 2005. Modern Food Microbiology. 6th ed. Van Nostrand Reinhold Publishing Co., New York, NY.

Klotz, M., S. Opper, K. Heeg, and S. Zimmermann. 2003. Detection of Staphylococcus aureus enterotoxins A to D by real-time fluorescence PCR assay. J. Clin. Microbiol. 41:4683-4687. https://doi .org/10.1128/JCM.41.10.4683-4687.2003.

Kornacki, J. L., and J. L. Johnson. 2001. Enterobacteriaceae, coliforms and Escherichia coli as quality and safety indicators. Pages 69-80 in Compendium of Methods for the Microbiological Examination of Foods. 4th ed. F. P. Downes and K. Ito, ed. American Public Health Association, Washington, DC.

Kuroda, M., T. Ohta, I. Uchiyama, T. Baba, H. Yuzawa, I. Kobayashi, L. Cui, A. Oguchi, K. Aoki, Y. Nagai, J. Lian, T. Ito, M. Kanamori, H. Matsumaru, A. Maruyama, H. Murakami, A. Hosoyama, Y. Mizutani-Ui, N. K. Takahashi, T. Sawano, R. Inoue, C. Kaito, K. Sekimizu, H. Hirakawa, S. Kuhara, S. Goto, J. Yabuzaki, M. Kanehisa, A. Yamashita, K. Oshima, K. Furuya, C. Yoshino, T. Shiba, M. Hattori, N. Ogasawara, H. Hayashi, and K. Hiramatsu. 2001. Whole genome sequencing of meticillin-resistant Staphylococcus aureus. Lancet 357:1225-1240. https://doi.org/10.1016/S0140 -6736(00)04403-2.

Lancette, G. A., and S. R. Tatini. 2001. Staphylococcus aureus. Pages 387-400 in Compendium of Methods for the Microbiological Examination of Foods. 4th ed. F. P. Downes and K. Ito, ed. American Public Health Association, Washington, DC.

Le Loir, Y., F. Baron, and M. Gautier. 2003. Staphylococcus aureus and food poisoning. Genet. Mol. Res. 2:63-76.

Le Marc, Y., L. Valík, and A. Medved'ová. 2009. Modelling the effect of the starter culture on the growth of Staphylococcus aureus in milk. Int. J. Food Microbiol. 129:306-311. https://doi.org/10 $.1016 /$ j.ijfoodmicro.2008.12.015.

MacFaddin, J. F. 1980. Biochemical Tests for Identification of Medical Bacteria. 2nd ed. Williams and Wilkins, Baltimore, MD.
Merck. 1993. Reactivos, Diagnostica, Productos Quimicos 1992/93. Merck, Darmstadt, Germany.

Neal, C., and H. Calbert. 1955. The use of 2, 3, 5-triphenyltetrazolium chloride as a test for antibiotic substances in milk. J. Dairy Sci. 38:629-633. https://doi.org/10.3168/jds.S0022-0302(55)95015-3.

Nouaille, S., L. Rault, S. Jeanson, P. Loubière, Y. Le Loir, and S. Even. 2014. Contribution of Lactococcus lactis reducing properties to the downregulation of a major virulence regulator in Staphylococcus aureus, the agr system. Appl. Environ. Microbiol. 80:70287035. https://doi.org/10.1128/AEM.02287-14.

Otero, A., M. L. Garcia, M. C. Garcia, B. Moreno, and M. S. Bergdoll. 1990. Production of staphylococcal enterotoxins $\mathrm{C}_{1}$ and $\mathrm{C}_{2}$ and thermonuclease throughout the growth cycle. Appl. Environ. Microbiol. 56:555-559.

Penido, F. C. L., F. B. Piló, S. H. C. Sandes, Á. C. Nunes, G. Colen, E. S. Oliveira, C. A. Rosa, and I. C. A. Lacerda. 2018. Selection of starter cultures for the production of sour cassava starch in a pilot-scale fermentation process. Braz. J. Microbiol. 49:823-831. https://doi.org/10.1016/j.bjm.2018.02.001.

Ross, R. P., C. Stanton, C. Hill, G. F. Fitzgerald, and A. Coffey. 2000 Novel cultures for cheese improvement. Trends Food Sci. Technol. 11:96-104. https://doi.org/10.1016/S0924-2244(00)00057-1.

Sandes, S., L. Alvim, B. Silva, L. Acurcio, C. Santos, M. Campos, C. Santos, J. Nicoli, E. Neumann, and Á. Nunes. 2017. Selection of new lactic acid bacteria strains bearing probiotic features from mucosal microbiota of healthy calves: Looking for immunobiotics through in vitro and in vivo approaches for immunoprophylaxis applications. Microbiol. Res. 200:1-13. https://doi.org/10.1016/j .micres.2017.03.008.

Sandes, S. H., L. B. Alvin, B. C. Silva, D. F. Zanirati, L. R. Jung, J. R. Nicoli, E. Neumann, and A. C. Nunes. 2014. Lactobacillus species identification by amplified ribosomal $16 \mathrm{~S}-23 \mathrm{~S}$ rRNA restriction fragment length polymorphism analysis. Benef. Microbes 5:471-481. https://doi.org/10.3920/BM2013.0092.

Sant'Anna, F. M., S. U. Wetzels, S. H. S. Cicco, R. C. Figueiredo, G. A. Sales, N. C. Figueiredo, C. A. Nunes, S. Schmitz-Esser, E. Mann, M. Wagner, and M. R. Souza. 2019. Microbial shifts in Minas artisanal cheeses from the Serra do Salitre region of Minas Gerais, Brazil throughout ripening time. Food Microbiol. 82:349362. https://doi.org/10.1016/j.fm.2019.02.016.

Silva, R. S. Caracterização da microbiota da glândula mamária bovina saudável e com mastite subclínica e seleção de bactérias potencialmente probióticas isoladas desse ecossistema. 2016. PhD thesis, Instituto de Ciências Biológicas, Universidade Federal de Minas Gerais, Brazil.

Stamford, T. L. M., C. G. M. Silva, R. A. Mota, and A. Cunha Neto. 2006. Enterotoxigenicidade de Staphylococcus spp. isolados de leite in natura. Food Sci. Technol. (Campinas) 26:41-45. https://doi .org/10.1590/S0101-20612006000100007.

Ulve, V. M., C. Monnet, F. Valence, J. Fauquant, H. Falentin, and S. Lortal. 2008. RNA extraction from cheese for analysis of in situ gene expression of Lactococcus lactis. J. Appl. Microbiol. 105:13271333. https://doi.org/10.1111/j.1365-2672.2008.03869.x. 